\title{
Database of anthropogenic vegetation of the Urals and adjacent territories
}

\author{
Yaroslav Golovanov ${ }^{*}$, and Larisa Abramova \\ South-Ural Botanical Garden-Institute of the Ufa Federal Scientific Center RAS, 450080, Ufa, \\ Russian Federation
}

\begin{abstract}
The main data on the geobotanical database - Database of antropogenic vegetation of Urals and adjacent territories registered in the Global Index of Vegetation-Plot Databases and the European Vegetation Archive are presented. The database includes more than 4,000 complete geobotanical relevés made between 1984 and 2020. The database contains the territories of 3 subjects of the Russian Federation (the Republic of Bashkortostan, Orenburg, Chelyabinsk regions) and 1 - the Republic of Kazakhstan (Aktobe region). For each relevés, a complete list of species with indication of abundance in points on the Braun-Blanquet scale. The main indicators (total cover, average height of the grass, etc.). For most descriptions, GPS coordinates and location are given. The ecological conditions were assessed with use of average values of E. Landolt scale. In the J. Braun-Blanquet classification system, all communities included in the database belong to nine vegetation classes ( 7 anthropogenic and 2 semi-natural), 75 associations and various types of communities. Geobotanical relevés with the dominance of such aggressive invasive species (Acer negundo, Ambrosia psylostachya, Echinocystis lobata, Elodea canadensis, Solidago canadensis, Heracleum sosnowskyi, Hordeum jubatum, Xanthium albinum etc.) are also included in the database.
\end{abstract}

Currently topical problem of phytocenology is creation of the centralized databases on geobotanical releves for the majority of regions of Russia. Similar databases serve for the centralized storage of large volumes of geobotanical information and also exchange of geobotanical material between colleagues from Russia and other countries by means of their registration in different archives. The largest archives of vegetation pots today are the European Vegetation Archive (EVA) [1] and the international consortium sPlot [2]. Today, 311 databases with 3628497 vegetation plots are registered in the Global Index of Vegetation-Plant Databases (GIVD). Such databases make it possible to study the global patterns of taxonomic, phylogenetic and functional diversity at the level of plant communities. Geobotanical databases including anthropogenic vegetation types are of particular interest in the study of global anthropogenic changes in vegetation. To date, a small number of special geobotanical databases on anthropogenic vegetation types have

\footnotetext{
*Corresponding author: jaro1986@mail.ru
} 
been registered in GIVD in Russia (for example, Database of weed vegetation of the Northwest of the European part of Russia etc.).

For the first time, the database of anthropogenic vegetation of the Urals and adjacent territories was registered in the Global Vegetation Data Index (GIVD) [3] in 2020, in the same year it was included in the European Vegetation Archive (EVA) [1]. For today the database (00-RU-008 - Database of antropogenic vegetation of Urals and adjacent territories, http://www.givd.info/ID/00-RU-008) included more than 4000 complete geobotanical relevés. All relevés were entered into the database using TURBOVEG software.

The database includes both published and unpublished geobotanical relevés. They cover the time period from 1984 to 2020 . The share of geobotanical relevés in the database varied by time intervals. 1980-1989 - 20\% geobotanical relevés, 1990-1999 - 6\%, 2000-2009$26 \%, 2010-2020-48 \%$. The most active database has been replenished in the last decade, in connection with active studies of vegetation of settlements and communities with the participation of alien species of the Bashkortostan Republic [4-17].

The database contains the territories of 3 subjects of the Russian Federation (the Republic of Bashkortostan, Orenburg, Chelyabinsk regions) and 1 - the Republic of Kazakhstan (Aktobe region). From the position of physical and geographical zoning, the covered territory is located at the junction of the East European Plain and the Ural mountain country, and also includes the Subural plateau.

The geobotanical relevés making a database were carried out by standard methodic, as a rule, on platforms $10 \times 10 \mathrm{~m}$ and also in natural borders of phytocoenosis (1-10 sq.m - 32\% of geobotanical relevés, 11-100 sq.m - 67\%, 101-1000 $\mathrm{m}^{2}-1 \%$ ). Complete lists of species on sample plots with indication of abundance in points on the Braun-Blanquet scale are presented: $r$ - species on the sample plots is found in single individuals; +- species has cover up to $1 \% ; 1$ - from 1 to $5 \% ; 2$ - from 5 to $25 \% ; 3$ - from 25 to $50 \% ; 4$ - from 50 to $75 \% ; 5$ - above $75 \%$. More than $70 \%$ of geobotanical relevés have GPS coordinates.

The database also provides environmental characteristics for each geobotanical relevés. The ecological conditions were assessed with use of average values of E. Landolt [18] scale. Average values are calculated on the following scales: humidification $(\mathbf{M})$, acidity $(\mathrm{R})$, soil richness with mineral nutrition elements $(\mathrm{N})$, humus $(\mathrm{H})$ content, mechanical composition and soil structure (D), illumination (L) etc.

The total list of collectors totals 21 people, the proportion of geobotanical relevés of various authors included in the database is shown in Table 1.

Table 1. Contribution of collectors to the database

\begin{tabular}{|l|c|c|}
\hline \multicolumn{1}{|c|}{ Collector } & $\begin{array}{c}\text { Number of } \\
\text { geobotanical relevés }\end{array}$ & $\begin{array}{c}\text { Database geobotanical } \\
\text { relevés percentage }\end{array}$ \\
\hline Golovanov Ya.M. & 1978 & 46.7 \\
\hline Sujundukova G.Ya. & 436 & 10.3 \\
\hline Abramova L.M. & 390 & 9.2 \\
\hline Ishbirdin A.R. & 298 & 7.0 \\
\hline Solomesch A.I. & 199 & 4.7 \\
\hline $\begin{array}{l}\text { Zhigunov O.Yu., } \\
\text { Anischenko I.E. }\end{array}$ & 184 & 4.3 \\
\hline Ryabova T.G. & 179 & 4.2 \\
\hline
\end{tabular}




\begin{tabular}{|l|c|c|}
\hline Sajfullina N.M. & 124 & 2.9 \\
\hline Sachapov M.T. & 99 & 2.3 \\
\hline Mullagulov R.T. & 89 & 2.1 \\
\hline Michailova V.A. & 62 & 1.5 \\
\hline Khusainova S.A. & 58 & 1.4 \\
\hline Ibragimov I. & 44 & 1.0 \\
\hline Rudakov K.M. & 30 & 0.7 \\
\hline Klotz S., Kock U. & 22 & 0.5 \\
\hline Petrov S.S. & 22 & 0.5 \\
\hline Fedorov N.I. & 10 & 0.2 \\
\hline Sultangareeva L.M. & 7 & 0.2 \\
\hline Khaziahmetov R.M. & 6237 & 0.1 \\
\hline Total: & & 100.0 \\
\hline
\end{tabular}

The database presents geobotanical relevés of various types of vegetation: $2 \%$ of geobotanical relevés of forest phytocoenoses and $98 \%$ of grass. The composition of grass communities contains $4 \%$ of water and coastal-water coenoses. Most of the geobotanical relevés were made in anthropogenic phytocoenoses, $2 \%$ in semi-natural ones.

In the J. Braun-Blanquet classification system [19], all communities included in the database belong to nine vegetation classes. The names of vegetation classes are given by "Vegetation of Europe..." [20].

Anthropogenic vegetation.

Class Sisymbrietea Gutte et Hilbig 1975. Zoo-anthropogenic and modern anthropogenic vegetation of animal shelters and disturbed ruderal sites in cool- and cold-temperate regions of Eurasia. 13 associations.

Class Digitario sanguinalis-Eragrostietea minoris Mucina, Lososová et Šilc in Mucina et al. 2016. Thermophilous grass-rich anthropogenic vegetation rich in summer-annual $\mathrm{C} 4$ species in the southern nemoral, mediterranean, steppe and semi-desert zones of Europe. 6 associations.

Class Polygono-Poetea annuae Rivas-Mart. 1975. Subcosmopolitan therophyte-rich dwarf-herb vegetation of trampled habitats. 7 associations.

Class Artemisietea vulgaris Lohmeyer et al. in Tx. ex von Rochow 1951. Perennial (sub)xerophilous ruderal vegetation of the temperate and submediterranean regions of Europe. 21 associations.

Class Epilobietea angustifolii Tx. et Preising ex von Rochow 1951. Tall-herb seminatural perennial vegetation on disturbed forest edges, nutrient-rich riparian fringes an in forest clearings in the temperate and boreal zones of Eurasia. 17 associations.

Class Bidentetea Tx. et al. ex von Rochow 1951. Summer-annual pioneer vegetation of seasonally flooded nutrient-rich river alluvia, lacustrine banks and heavily nutrient-loaded anthropogenic habitats of boreo-temperate Europe and North Africa. 5 associations. 
Class Robinietea Jurko ex Hadač et Sofron 1980. Seral forest-clearing and anthropogenic successional scrub and thickets on nutrient-rich soils of temperate Europe. 1 associations.

Semi natural vegetation.

Class Molinio-Arrhenatheretea Tx. 1937. Anthropogenic managed pastures, meadows and tall-herb meadow fringes on fertile deep soils at low and mid-altitudes (rarely also high altitudes) of Europe. The database includes anthropogenically transformed communities of the Cynosurion cristati Tx. 1947: city meadows, lawns, etc. 5 associations and different communities.

Class Festuco-Brometea Br.-B1. et Tx. ex Soó 1947. Dry grassland and steppe vegetation of mostly base- and colloid-rich soils in the submediterranean, nemoral and hemiboreal zones of Europe. The database includes anthropogenically transformed steppe communities found within human settlements. Different communities.

Invasive plant species are one of the leading components of plant communities of anthropogenic habitats. Included in the database are geobotanical relevés dominated by aggressive invasive species such as: Acer negundo, Ambrosia psylostachya, A. trifida, Bidens frondosa, Echinocystis lobata, Elodea canadensis, Iva xanthiifolia, Solidago canadensis, Heracleum sosnowskyi, Hordeum jubatum, Xanthium albinum etc. This allows us to study the distribution, invasive potential, and features of the invasions mechanisms at the regional and continental level. In the classification of communities with the dominance of invasive species, the Kopecký-Hejný deductive method [21] was used, along with the classic Braun-Blanquet method.

The main difficulty in case of its realization was unavailability of complete geobotanical relevés of a row of authors. So often in the dissertations are given only synoptic tables without full geobotanical relevés there are also a lost source of field data. Serious part is occupied also by final - the verification stage of the database formation. It consists in check of floristic composition of geobotanical relevés (identification of incorrectly determine species of plants, correction of the database in compliance with the current state of a taxonomy).

The creation of geobotanical database becomes an important part of modern geobotanical investigations. The preservation of field geobotanical materials in electronic form will benefit as modern scientists from Russia and around the world.

Acknowledgment. The study was carried out within the framework of the State Assignment no. AAAA-A18-118011990151-7 of the Southern Ural Botanical Garden-Institute (Ufa Federal Research Center, Russian Academy of Sciences).

\section{Reference}

1. M. Chytrý, B. Jiménez-Alfaro, I. Knollová, F. Landucci, J. Danihelka, M. Jiroušek, C. Marcenò, S.M. Hennekens, J.H.J. Schaminée, J. Dengler et al., App. Veg. Sci. 19, 1 (2016)

2. H. Bruelheide, B. Jiménez-Alfaro, O. Purschke, S. Haider, U. Jandt, F.M. Sabatini, I. Kühn, J. Dengler, S.M. Hennekens, J. H. J. Schaminée, M. Chytrý, et al., J. Veg. Sci. 30, 2 (2019)

3. J. Dengler, F. Jansen, F. Glöckler, R. K. Peet, M. De Cáceres, M. Chytrý, et al., J. Veg. Sci., 22 (2011)

4. Ya. M. Golovanov, L. M. Abramova, Rast. Ross. 38 (2020)

5. L. Arepieva, E. Kulikova, L. Abramova, Y. Golovanov, A. Bulokhov, A. Kharin, Thaiszia, 30, 2 (2020) 
6. I. E. Anishchenko, Ya. M. Golovanov, O. Yu. Zhigunov, L. M. Abramova, Rast. Ross. 36 (2019)

7. L. M. Abramova, Ya. M. Golovanov, Rast. Ross. 36 (2019)

8. Ya. M. Golovanov, S. M. Yamalov, L. M. Abramova, Bot. Pacif. 6, 1 (2017)

9. Ya. M. Golovanov, Rast. Ross. 30 (2017)

10. L. M. Abramova, Ya. M. Golovanov, Rast. Ross. 28 (2016)

11. Ya. M. Golovanov, L. M. Abramova, A. A. Muldashev, Russ. J. Biol. Inv. 7, 3 (2016)

12. L. M. Abramova, Rast. Ross. 27 (2015)

13. Ya. M. Golovanov, S. M. Yamalov, L. M. Abramova, Rast. Ross. 27 (2015)

14. Ya. M. Golovanov, P. S. Shirokich, L. M. Abramova, Rast. Ross. 25 (2014)

15. Ya. M. Golovanov, L. M. Abramova, Rast. Ross. 22 (2013)

16. Ya. M. Golovanov, L. M. Abramova, Rast. Ross. 21 (2012)

17. L. M. Abramova, Rast. Ross. 19 (2011)

18. E. Landolt, Veröff. Geobot. Inst. ETH. Stift. Rübel. Zürich. 64 (1977)

19. J. Braun-Blanquet Pflanzensoziologie. Grundzüge der Vegetationskunde (Wien, NewYork, 1964)

20. L. Mucina, H. Bültmann, K. Dierssen, J.-P. Theurillat, T. Raus, A. Čarni, J. Dengler, M. Chytrý, et al., App. Veg. Sci. 19 (2016)

21. K. Kopecký, S. Hejný, Vegetatio. 29, 1 (1974) 